\title{
DETERMINASI KEJADIAN PERILAKU SEKSUAL PRANIKAH DALAM AKTIVITAS PACARAN REMAJA DI KALIMANTAN TENGAH
}

\section{Determination of Premarital Sexual Behavior in Dating Activities of Adolescents in Central Kalimantan}

\author{
Shesanthi Citrariana ${ }^{\text {** }}$ \\ Risqika Yuliatantri $\mathbf{P}^{2}$ \\ Halida Suryadini ${ }^{3}$ \\ Muhammad Dawam ${ }^{4}$ \\ Awumistiko ${ }^{5}$ \\ *I Farmasi, Universitas \\ Muhammadiyah Palangkaraya, \\ Palangka Raya, Kalimantan \\ Tengah, Indonesia \\ 2 Farmasi, Universitas \\ Muhammadiyah Palangkaraya, \\ Palangka Raya, Kalimantan \\ Tengah, Indonesia \\ 3 Farmasi, Universitas \\ Muhammadiyah Palangkaraya, \\ Palangka Raya, Kalimantan \\ Tengah, Indonesia \\ ${ }^{4}$ Puslitbang Kependudukan, \\ Jakarta, Indonesia \\ 5 BKKBN, Kalimantan Tengah, \\ Indonesia \\ *email: \\ shesanthi.citrariana@gmail.com
}

\section{Kata Kunci:}

karakteristik

determinasi

perilaku seksual pranikah

\section{Keywords:}

characteristics

determination

premarital sexual behavior

\begin{abstract}
Abstrak
Berdasarkan survei SDKI 2017 BKKBN, sebagian besar remaja wanita (80\%) dan pria (84\%) melaporkan pernah berpacaran. Kelompok umur 15-17 tahun merupakan umur remaja mulai berpacaran. Aktivitas pacaran remaja banyak mengarah pada perilaku seksual, seperti berpegangan tangan, merangkul, mencium bibir, menyentuh bagian sensitif, ataupun melakukan hubungan seksual. Penelitian ini bertujuan mengetahui pengaruh karakteristik latar belakang remaja (umur, daerah tempat tinggal, tingkat pendidikan) dan pola pergaulan (memiliki teman melakukan seks pranikah, memiliki dorongan karena teman, mempengaruhi teman melakukan seks pranikah, menganggap keperawanan penting) terhadap kejadian seks pranikah di Kalimantan Tengah Tahun 2017. Data sekunder diperoleh dari survei SDKI 2017. Analisis data menggunakan metode univariat; bivariat (uji spearman rho); dan multivariat (uji regresi logistik). Hasil penelitian menunjukan responden yang pernah melakukan orientasi perilaku seksual sebanyak $88 \%$ dan yang tidak sebanyak 12\%. Analisis korelasi menjelaskan adanya hubungan signifikan antara daerah tempat tinggal dengan perilaku seksual, responden yang tinggal di kota memiliki resiko 3,47 kali lebih rentan melakukan perilaku seksual $(\alpha<0,05=0,021 ; O R=3,47)$. Selain itu, ada cukup bukti untuk menyatakan bahwa ada hubungan antara tingkat pendidikan dengan perilaku seksual pranikah, responden dengan pendidikan SLTA keatas memiliki resiko 2,7I kali lebih rentan melakukan perilaku seksual $(\alpha<0,10=0,066$; $O R=2,71)$. Sedangkan variabel lain baik dari karakteristik latar belakang dan pola pergaulan tidak memiliki hubungan signifikan/tidak memiliki pengaruh dengan perilaku seksual pranikah. Sehingga dapat disimpulkan bahwa karakteristik latar belakang berupa daerah tinggal (Sig Wald < 0,05) memberikan pengaruh parsial signifikan terhadap kejadian perilaku seksual pranikah remaja di Kalimantan Tengah.
\end{abstract}

\begin{abstract}
Based on the 2017 IDHS survey, most of adolescent women (80\%) and men (84\%) reported dating. The 15-17 years is age group when adolescents start dating. Teenage dating activities lead to sexual behavior, such as holding hands, hugging, kissing lips, touching sensitive parts, and having sex. This study aims to determine the influence of the background characteristics of adolescents (age, area of residence, level of education) and social patterns (having friends having premarital sex, having the urge because of friends, influencing friends to have premarital sex, considering virginity important) on the incidence of premarital sex in Central Kalimantan 2017. Secondary data were obtained from the 2017 IDHS survey. Data analysis was performed by univariate; bivariate (Spearman rho test); and multivariate (logistic regression test). The results showed that $88 \%$ respondents who had sexual behavior orientation and $12 \%$ who did not. The correlation analysis explains that there is a significant relationship between premarital sexual behavior and the area of residence, respondents who live in cities are 3.47 times more likely to commit premarital sexual behavior $(\alpha<0,05=0,021 ; O R=3.47)$. In addition, there is sufficient evidence to suggest relationship between premarital sexual behavior and education level, respondents who attend high school and above 2.71 times more likely to have premarital sexual behavior $(\alpha<0,10=0,066 ; O R=2.7 I)$. Meanwhile, other variables, both from background characteristics and social patterns, no significant relationship/have no influence with premarital sexual behavior. So it can be concluded that the background characteristics in the area of residence (Sig Wald <0.0) has significant partial effect on the incidence of premarital sexual behavior of adolescents in Central Kalimantan.
\end{abstract}




\section{PENDAHULUAN}

Remaja adalah kelompok usia rentan terhadap perilaku berisiko, termasuk perilaku seks pranikah, karena pada masa remaja terjadi berbagai perubahan baik secara fisik yaitu pematangan organ reproduksi, perubahan emosi yang menyebabkan adanya perubahan sikap dan tingkah laku serta pola pikir remaja serta perubahan sosial. Pada masa ini remaja menjadi rentan terlibat dalam perilaku berisiko (termasuk perilaku seks pranikah). Diketahui prevalensi remaja yang melakukan seks pranikah sebesar $41 \%$, dan angka ini menunjukkan tren peningkatan dari tahun ke tahun (Center for Disease Control and Prevention, 2015).

Istilah adolescence atau remaja berasal dari kata latin adolescre yang berarti tumbuh, tumbuh menjadi dewasa atau tumbuh menuju kematangan. Istilah adolescence mempunyai arti luas, mencakup kematangan mental, emosional, sosial dan fisik. Lazimnya masa remaja dianggap mulai pada saat anak secara seksual menjadi matang dan berakhir saat mencapai usia matang secara hukum. Masa remaja disebut juga sebagai periode perubahan, tingkat perubahan dalam sikap, dan perilaku selama masa remaja sejajar dengan perubahan fisik (Fhadila, 2017).

Menurut Sarwono perilaku seksual adalah segala tingkah laku yang di dorong oleh hasrat seksual. Perilaku ini bisa dilakukan sebelum menikah atau dilakukan pada saat pacaran maka disebut dengan perilaku seksual pranikah. Lebih lanjut perilaku seksual pada remaja dari berbagai hasil penelitian di berbagai negara adalah: pelukan dan pegangan tangan, berciuman, meraba payudara, meraba alat kelamin dan melakukan hubungan seks (Sarwono, 20II). Kecenderungan remaja untuk melakukan perilaku seks pranikah baik disebabkan karena meningkatnya dorongan seksual akibat pengaruh hormone seks pada remaja yaitu hormon endrogen dan testosteron pada remaja pria, serta progesteron dan esterogen pada remaja wanita. Hormon-hormon tersebut juga menyebabkan terjadinya perubahan bentuk tubuh pada remaja baik yang menyangkut tinggi badan juga menyebabkan munculnya tanda seks skunder dan seks primer pada remaja (Nasir et al., 2013).

Anak yang sedang beranjak dari usia remaja menuju desawa atau disebut dengan masa transisi biasanya memiliki sifat yang ingin lebih bebas dalam mengatur kehidupan pergaulannya (Pinandari et al., 20I5). Pacaran bagi sebagian remaja bukan hal yang asing lagi karena adanya pengaruh westernisasi melalui mediamedia elektronik. Bahkan banyak remaja memiliki anggapan bahwa masa remaja adalah masa berpacaran, jadi remaja yang tidak berpacaran justru dianggap sebagai remaja yang kuno, kolot, tidak mengikuti perubahan zaman dan dianggap kuper atau kurang pergaulan. Akibatnya sering terjadi perilaku seks di luar nikah, dampak dari hal tersebut adalah meningkatnya angka kejadian pernikahan usia dini yang dilakukan by accident (Desiningrum \& Sari, 2017).

Berdasarkan survei SDKI 2017 yang dilakukan Badan Kependudukan dan Keluarga Berencana Nasional sebagian besar remaja wanita $(80 \%)$ dan sebagian besar remaja pria (84\%) melaporkan pernah berpacaran. Kelompok umur 15-17 tahun merupakan umur mulai pacaran pertama kali yang paling banyak disebutkan yaitu, $45 \%$ pada wanita dan $44 \%$ pada pria. Perilaku pacaran berdasarkan data SDKI yang mengarah pada aktivitas seksual meliputi: berpegangan tangan merupakan hal yang paling banyak dilakukan oleh wanita dan pria (64\% dan 75\%), berpelukan (wanita $17 \%$ dan pria 33\%), berciuman bibir (pria 50\% dan wanita $30 \%$ ). Perilaku pacaran dengan aktivitas seperti berpegangan tangan, berpelukan, dan ciuman bibir akan menggiring pada tindakan seksual pranikah seperti yang telah dipaparkan pada data SDKI bahwa remaja di Indonesia dalam aktifitas pacaran melakukan hubungan seksual dengan jumlah proporsi sebesar 7,6\% atau 12.612 remaja pada pria dan I,5\% atau $9.97 \mid$ remaja pada wanita (BKKBN, 20I7).

Kebebasan dalam pacaran remaja yang melakukan perilaku seksual pranikah dapat dipengaruhi oleh 
beberapa faktor, diantaranya adalah informasi, norma subjektif, dan intensi perilaku seksual. Pemberian informasi yang baik didukung dengan norma subjektif yang positif serta intensi perilaku seksual yang rendah maka akan menjadi faktor preventif bagi kejadian seks pranikah pada remaja. Faktor lain yang dapat mempengaruhi berdasarkan Data Laporan SDKIRemaja 2017 yang dilakukan oleh BKKBN adalah karakteristik latar belakang yang ada pada individu tersebut seperti umur, tingkat pendidikan, kuintil kekayaan, dan daerah tempat tinggal.

Di Indonesia sendiri telah banyak penelitian yang pernah dilakukan untuk melihat faktor-faktor yang berpengaruh terhadap perilaku seksual remaja diantaranya adalah: tentang "Pengaruh Aktivitas Seksual Pranikah, Ketaatan Beragama dan Sosial Ekonomi terhadap Kehamilan Remaja di Kecamatan Saptosari Gunungkidul” (Notoboro \& Magdalena, 2016); "Hubungan Antara Pengetahuan Remaja Tentang Pendidikan Seks Dengan Perilaku Seksual Pranikah Pada Remaja di Riau” (Firza, 201I); "Pengalaman Berkeluarga Pada Wanita yang Menjalani Married by Accident Studi Fenomenologis Pernikahan Karena Kehamilan Diluar Nikah di Semarang” (Desiningrum \& Sari, 2017); “Hubungan Peran Orang Tua dengan Inisiasi Seks Pranikah pada Remaja di Prodi SI Farmasi Universitas Muhammadiyah Kalimantan Timur" (Winarti \& Alamsyah, 2020).

Sedangkan dalam penelitian ini bertujuan untuk melihat ada tidaknya korelasi yang signifikan $(\alpha)$ dan besarnya pengaruh (OR) dari karakteristik latar belakang responden (umur, tingkat pendidikan, daerah tempat tinggal) dan pola pergaulan responden (memiliki teman yang telah melakukan seks pranikah, memiliki dorongan karena teman yang telah melakukan seks pranikah, mempengaruhi teman melakukan seks pranikah, menganggap keperawanan penting) terhadap perilaku seksual remaja dalam aktivitas pacaran remaja khususnya Kalimantan Tengah menggunakan Data SDKI-Remaja 2017.

\section{METODOLOGI}

Desain studi yang digunakan dalam penelitian ini cross sectional analitik menggunakan data Survei Demografi dan Kesehatan Indonesia (SDKI) tahun 2017. Studi cross sectional dapat dipahami sebagai studi yang mempelajari beberapa variabel pengamatan dalam satu waktu secara sekaligus guna mencari hubungan sebab akibat antara variabel independen terhadap variabel dependen (Swarjana, 20I2).

\section{- Partisipan}

Sampel yang digunakan berdasarkan pada rancangan sampel SDKI 2017. Desain sampling SDKI 2017 menggunakan kerangka Master Sampel Blok Sensus dari hasil sensus penduduk 2010 (SP2010) yang merupakan daftar rumah tangga dari blok sensus terpilih. Responden dari Kalimantan Tengah yang digunakan sebagai sampel dalam penelitian ini adalah responden remaja (I5-24 tahun) yang memiliki data jawaban lengkap pada butir pertanyaan yang digunakan dalam penelitian ini, yaitu: Bagian I (Latar Belakang Responden) dan Bagian 17 (Pacaran dan Perilaku Seksual) di lembar kuesioner SDKI 2017, sehingga diperoleh jumlah responden perempuan sebanyak 44 orang dan laki-laki 73 orang.

\section{- Pengukuran}

Alat ukur yang digunakan dalam penelitian ini adalah lembar kuesioner SDKI Remaja Bagian I yaitu Latar Belakang Responden dengan butir pertanyaan nomor 103 dan 108 serta Bagian 17 yaitu Pacaran dan Perilaku Seksual dengan butir pertanyaan nomor 1703, 1704, 1705, 1712, 1713, 1718, dan 1723.

\section{- Prosedur}

Penelitian ini menggunakan sumber data sekunder dimana raw data SDKI tahun 2017 yang diterima oleh peneliti dengan menyampaikan surat permohonan untuk memperoleh raw data dari BKKBN Pusat dan Kalimantan Tengah. Raw data yang diperoleh kemudian dilakukan seleksi data yang diperlukan untuk dapat dianalisa secara statistika. 


\section{- Teknik Analisis}

Variabel dalam penelitian ini terdiri dari:

a. Variabel terikat

(Y): perilaku pranikah (pernah = I; tidak pernah $=0$ );

b. Variabel bebas berdasarkan karakteristik latar belakang $(\mathrm{X})$ :

$X_{1}$ : Umur pertamakali berpacaran $(>17$ tahun $=1 ;<17$ tahun $=0$ ),

$\mathrm{X}_{2}$ : Pendidikan (SLTA ke atas $=1 ;$ maksimal SLTP $=0$ ),

X3: Klasifikasi daerah tempat tinggal kota/desa ( $\mathrm{I}=$ perkotaan; 0 = perdesaan);

c. Variabel bebas berdasarkan pola pergaulan (Z):

ZI: Memiliki teman yang telah melakukan seks pranikah ( $\mathrm{Ya}=1$; Tidak $=0)$,

Z2: Memiliki dorongan karena teman $(Y a=1$; Tidak = $0)$,

Z3: Mempengaruhi teman melakukan seks pranikah $(\mathrm{Ya}=\mathrm{I} ;$ Tidak $=0)$,

Z4: Menganggap keperawanan penting $(\mathrm{Ya}=\mathrm{I}$; Tidak $=$ 0).

\section{a. Analisis univariat}

Analisis univariat digunakan untuk memberikan gambaran umum, data karakteristik latar belakang responden (umur, jenis kelamin, pendidikan, dan daerah tempat tinggal) dan pola pergaulan (Memiliki teman yang telah melakukan seks pranikah, Memiliki dorongan karena teman, Mempengaruhi teman melakukan seks pranikah, Menganggap keperawanan penting) disajikan dalam bentuk distribusi frekuensi dan presentase (Notoatmodjo, 2010).

$$
\mathrm{X}=\frac{\mathrm{n}}{\mathrm{N}} \times 100 \%
$$

Keterangan:

$X \quad$ : nilai presentase

$\mathrm{n} \quad$ : frekuensi yang diperoleh dari tiap kelompok

$\mathrm{N} \quad$ : jumlah responden

\section{b. Analisis bivariate}

Analisis bivariat dilakukan terhadap dua variable yang diduga atau berkorelasi (Notoatmodjo, S. 2010). Dalam penelitian ini analisis bivariat ingin mengetahui hubungan antara karakteristik latar belakang responden dan pola pergaulan terhadap perilaku seksual pranikah. Uji bivariate yang digunakan adalah Spearman Rho yang merupakan uji non-parametrik untuk variabel yang berskala nominal. Mencari Spearman Rho dengan rumus:

$$
\rho_{x y}=1-\frac{6 \sum d^{2}}{N\left(N^{2}-1\right)}
$$

Keterangan:

$$
\begin{array}{ll}
\text { Pxy } & \text { : koefisien korelasi spearman } \\
\text { d } & \text { : perbedaan antara kedua ranking } \\
\mathrm{N} & \text { : frekuensi yang diharapkan }
\end{array}
$$

Untuk mengetahui hubungan antara karakteristik dan pola pergaulan dengan perilaku seksual remaja digunakan taraf signifikan yaitu $\alpha(0,05)$ : I) Apabila $p \leq$ $0,05=$ Ho ditolak, berarti ada hubungan antara karakteristik latar belakang dan pola pergaulan dengan perilaku seksual remaja, 2) Apabila $\mathrm{P}>0,05=\mathrm{Ho}$ diterima, berarti tidak ada hubungan antara karakteristik latar belakang dan pola perilaku dengan perilaku seksual remaja.

Analisa mutivariat menggunakan regresi logistik adalah suatu model matematik yang digunakan untuk mempelajari hubungan satu atau beberapa variable independen dengan satu variabel dependen yang bersifat dikotomi. Seperti analisis regresi pada umumnya, metode ini menggunakan beberapa variable bebas, baik numerik maupun kategori (binary) (Hosmer, 20I I). Persamaan regresi logistik:

$$
\begin{aligned}
& \operatorname{Logit}(Y)=a+b_{1} x_{1}+\ldots .+b_{k} x_{k} \\
& P_{(Y)}=\frac{1}{1+\operatorname{Exp}^{-(\log i t Y)}}=\frac{1}{1+\operatorname{Exp}^{-\left(a+b_{1} x_{1}+\ldots .+b_{k} x_{k}\right)}} \\
& \text { OR }=\operatorname{Exp}^{(\mathrm{b})}=\text { Exponensial }^{(\mathrm{b})}=\mathrm{e}^{(\mathrm{b})}
\end{aligned}
$$




\section{Keterangan:}

$\mathrm{P}(\mathrm{Y})$ : Probabilitas seorang individu untuk mengalami $Y=I$

OR (Odds Ratio): Risiko kelompok $X=I$ untuk mengalami $Y=I$ dibandingkan dengan kelompok $X=0$.

\section{HASIL DAN PEMBAHASAN}

Perilaku seksual pranikah adalah perilaku seksual yang dilakukan remaja tanpa adanya ikatan perkawinan. Variabel ini bertipe nominal dengan jawaban pernah dan tidak pernah. Seseorang dikatakan melakukan seksual pranikah, jika sudah melakukan salah satu dari aktivitas berpegangan tangan, merangkul, mencium bibir, menyentuh bagian tubuh sensitif, dan melakukan hubungan seksual. Berdasarkan tabel di atas diketahui bahwa sebanyak $88 \%$ responden pernah melakukan perilaku seksual pranikah. Dari seluruh responden, diketahui bahwa $62,4 \%$ nya adalah laki-laki dan $37,6 \%$ nya adalah perempuan.

Remaja adalah generasi penerus bangsa, yang diharapkan di masa depan mampu meneruskan tongkat estafet kepemimpinan bangsa. Kesadaran moral dan kesehatan reproduksi merupakan bekal yang sangat penting bagi remaja dalam menghadapi masa depan yang terus berkembang di era modern. Perilaku pergaulan remaja saat ini sedikit banyak telah berubah dengan adanya pengaruh dunia barat yang lebih bebas dan cenderung jauh dari nilai-nilai moral ketimuran yang ada di Indonesia (Aisyah, 20/3). Sudarsono berpendapat bahwa anak remaja sebagai anggota masyarakat selalu mendapat pengaruh dari keadaan masyarakat dan lingkungannya. Pengaruh yang dominan adalah akselerasi perubahan sosial yang ditandai dengan peristiwa yang sering menimbulkan ketegangan seperti persaingan dalam perekonomian, pengangguran, media massa, dan fasilitas hiburan lainnya. Kenakalan remaja saat ini dirasa telah mencapai tingkat yang cukup meresahkan bagi masyarakat. Kondisi ini memberikan dorongan kuat pada pihak-pihak yang bertanggung jawab mengenai masalah ini, seperti kelompok edukatif di lingkungan sekolah (Sudarsono, 1991).

\section{a. Analisa Univariat}

Tabel I. Karakteristik latar belakang responden di Kalimantan Tengah

\begin{tabular}{|c|c|c|c|c|}
\hline \multirow{3}{*}{ No. } & \multirow{3}{*}{$\begin{array}{l}\text { Karakteristik } \\
\text { latar belakang }\end{array}$} & \multicolumn{2}{|c|}{ Perilaku Seksual } & \multirow[t]{3}{*}{ Jumlah } \\
\hline & & & Tidak & \\
\hline & & Pernah (\%) & $\begin{array}{l}\text { Pernah } \\
\text { (\%) }\end{array}$ & \\
\hline \multirow{3}{*}{ I. } & $\begin{array}{l}\text { Umur } \\
\text { pertamakali } \\
\text { berpacaran }\end{array}$ & & \multirow{3}{*}{$\begin{array}{l}9,4 \\
(I I) \\
2,6(3)\end{array}$} & \\
\hline & $<17$ tahun & $70, I(82)$ & & $79,5(93)$ \\
\hline & $\geq 17$ tahun & $17,9(2 \mid)$ & & $20,5(24)$ \\
\hline \multirow{3}{*}{2.} & $\begin{array}{l}\text { Tingkat } \\
\text { pendidikan }\end{array}$ & & & \\
\hline & Maksimal SMP & $13,7(16)$ & $4,3(5)$ & $\mid 7,9(2 \mid)$ \\
\hline & SMA keatas & 74,4 (87) & $7,7(9)$ & $82,1(96)$ \\
\hline \multirow{3}{*}{3.} & $\begin{array}{l}\text { Daerah tempat } \\
\text { tinggal }\end{array}$ & & \multirow{3}{*}{$\begin{array}{l}9,4 \\
(I I) \\
2,6(3)\end{array}$} & \\
\hline & Pedasaan & $40,2(47)$ & & $49,6(58)$ \\
\hline & Perkotaan & $47,8(56)$ & & $50,4(59)$ \\
\hline
\end{tabular}

Berdasarkan Tabel I hubungan karakteristik latar belakang responden dengan kejadian perilaku seksual pranikah diketahui bahwa umur pertama kali berpacaran dengan perilaku seks pranikah pada remaja yang menjadi responden survei sebanyak $70,1 \%$ remaja yang pernah melakukan perilaku seksual pranikah pertama kali berpacara sejak usia $<17$ tahun, sedangkan yang berumur $\geq 17$ tahun sebanyak $17,9 \%$. Informasi dari tabel juga diketahui sebanyak I2\% remaja belum pernah melakukan perilaku seksual pranikah, yang mana $9,4 \%$ diantaranya pertama kali berpacaran pada usia < 17 tahun, dan sisanya sebanyak $2,6 \%$ berpacaran pada usia $\geq 17$ tahun. Sebanyak $13,7 \%$ remaja yang pernah melakukan perilaku seksual pranikah berada pada jenjang pendidikan maksimal SMP dan $74,4 \%$ sudah menyelesaikan minimal jenjang pendidikan SMA. Sebanyak $7,7 \%$ responden tidak pernah melakukan perilaku seksual pranikah juga berada pada jenjang pendidikan SMA keatas. Empat puluh tiga persen responden remaja lainnya yang mengatakan tidak pernah melakukan perilaku seksual pranikah masih berada pada tingkat pendidikan maksimal SMP. Remaja yang menyatakan pernah melakukan perilaku seksual pranikah pada survei SDKI 
di Kalimantan Tengah dan menjadi subjek dalam penelitian ini sebanyak $88,0 \%$, terbagi atas $47,9 \%$ bertempat tinggal di daerah perkotaan dan 40,2\% di pedesaan. Pada sisi lain, 12,0\% responden yang tidak pernah melakukan perilaku seksual pranikah terdiri atas $9,4 \%$ responden yang tinggal di pedesaan, dan sisanya tinggal di perkotaan sebesar $2,6 \%$.

Hubungan antara pola pergaulan responden dengan kejadian perilaku seksual pranikah dari tabel 2 diketahui bahwa semua responden di Kalimantan Tengah memiliki teman yang pernah melakukan perilaku seksual pranikah. Sebanyak 19,7\% remaja yang menjadi responden penelitian ini pernah melakukan perilaku seksual pranikah (berpegangan tangan, perpelukan, berciuman bibir, meraba bagian sensitif, dan termasuk behubungan seks pranikah) karena dorongan teman, sedangkan $68,4 \%$ bukan karena terdorong oleh temannya. 12,0\% respon yang tidak pernah melakukan perilaku seksual. Survei ini mengumpukan informasi apakah seseorang juga mempengaruhi teman dalam melakukan perilaku seksual pranikah. Hasil analisis hubungan menggambarkan bahwa 78,6\% remaja yang pernah melakukan perilaku seksual pranikah tidak pernah memberikan pengaruh kepada teman untuk melakukan seksual pranikah. 9,4\% sisanya yang pernah melakukan perilaku seksual pranikah juga mengajak teman untuk melakukan kegiatan serupa. Namun, seluruh responden sepakat menganggap bahwa keperawanan merupakan sesuatu yang penting.

Tabel 2. Pola pergaulan responden di Kalimantan Tengah

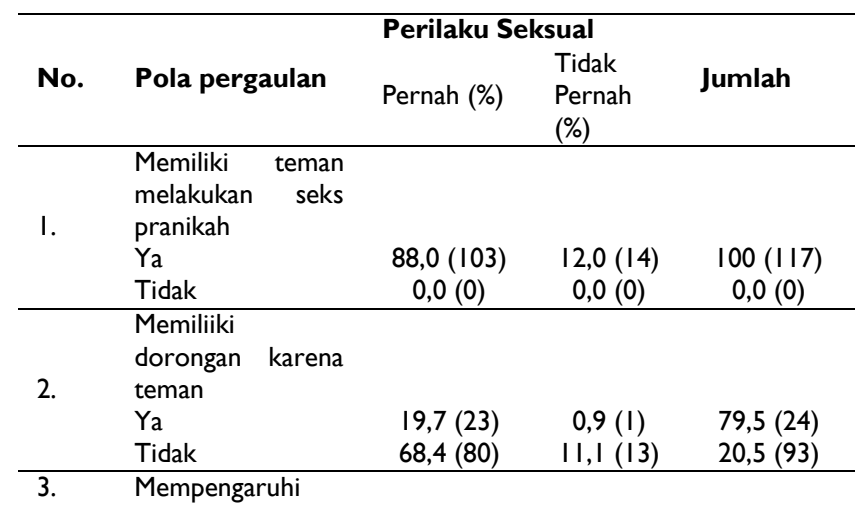

\begin{tabular}{llccc}
\hline & teman & & \\
& Ya & $9,4(1 \mathrm{I})$ & $0,0(0)$ & $9,4(1 \mathrm{I})$ \\
& Tidak & $78,6(92)$ & $9,4(14)$ & $90,6(106)$ \\
\hline & Menganggap & & & \\
& keperawanan & & & \\
4. & & & \\
& Penting & $88,0(103)$ & $12,0(14)$ & $100,0(117)$ \\
& Ya & $0,0(0)$ & $0,0(0)$ & $0,0(0)$ \\
\hline
\end{tabular}

\section{b. Analisa Bivariat}

Tabel 3. Analisis hubungan antara perilaku seksual pranikah dengan karakteristik latar belakang responden di Kalimantan Tengah

\begin{tabular}{|c|c|c|c|}
\hline \multirow{7}{*}{$\begin{array}{l}\text { Spearman's } \\
\text { rho }\end{array}$} & $\begin{array}{l}\text { Karakteristik } \\
\text { latar belakang }\end{array}$ & Korelasi & Nilai \\
\hline & \multirow{2}{*}{$\begin{array}{l}\text { Umur } \\
\text { pertamakali } \\
\text { berpacaran }\end{array}$} & Koefisien korelasi & $-0,008$ \\
\hline & & Sig. (2-tailed) & 0,929 \\
\hline & \multirow{2}{*}{$\begin{array}{l}\text { Tingkat } \\
\text { Pendidikan }\end{array}$} & Koefisien korelasi & 0,171 \\
\hline & & Sig. (2-tailed) & 0,066 \\
\hline & \multirow{2}{*}{$\begin{array}{l}\text { Daerah } \\
\text { Tinggal }\end{array}$} & Koefisien korelasi & 0,214 \\
\hline & & Sig. (2-tailed) & 0,021 \\
\hline
\end{tabular}

Analisis hubungan antara perilaku seksual pranikah pada aktivitas pacaran remaja dengan karakteristik latar belakang (umur, daerah tempat tinggal, dan tingkat pendidikan) dan juga pola pergaulan (memiliki teman yang pernah melakukan hubungan seksual pranikah, memiliki dorongan karena teman, mempengaruhi teman melakukan perilaku seksual pranikah, dan menganggap keperawanan penting dapat dilihat pada tabel 3.

Berdasarkan tabel 3 dan tabel 4 pada tingkat kesalahan jika digunakan 5\% diketahui bahwa dimiliki bukti untuk menyatakan terdapat hubungan antara Perilaku seksual pranikah dan daerah tempat tinggal $(\alpha<0,05=0,02 \mathrm{I})$. Jika dikaitkan dengan Analisa univariat diketahui bahwa lebih banyak remaja di Kalimantan Tengah yang tinggal di perkotaan melakukan perilaku seksual yaitu sebesar $47,8 \%$. Selain itu, pada tingkat kesalahan 10\%, ada cukup bukti untuk menyakan bahwa ada hubungan antara tingkat pendidikan dengan perilaku seksual pranikah $(\alpha<0,10=0,066)$, sedangkan variabel lain pada karakteristik latar belakang (umur pertamakali berpacaran $(\alpha=0,929)$ dan varibel dalam pola pergaulan (memiliki dorongan karena teman $\alpha=0,190$ dan mempengaruhi teman melakukan seks pranikah $\alpha$ 
$=0,202)$ memiliki hubungan yang tidak signifikan $(\alpha>0,05)$. Sedangkan variabel lain dalam pola pergaulan (memiliki teman yang mekukan prilaku seksual dan menganggap keperawanan penting) tidak memiliki pengaruh.

Tabel 4. Analisis hubungan antara perilaku seksual pranikah dengan pola pergaulan responden di Kalimantan Tengah

\begin{tabular}{|c|c|c|c|}
\hline \multirow{9}{*}{$\begin{array}{l}\text { Spearman's } \\
\text { rho }\end{array}$} & Pola pergaulan & Korelasi & Nilai \\
\hline & \multirow{2}{*}{$\begin{array}{l}\text { Memiliki teman yang } \\
\text { melakukan } \\
\text { seksual }\end{array}$} & $\begin{array}{l}\text { Koefisien } \\
\text { korelasi }\end{array}$ & . \\
\hline & & Sig. (2-tailed) & . \\
\hline & \multirow{2}{*}{$\begin{array}{l}\text { Memiliki dorongan } \\
\text { karena teman }\end{array}$} & $\begin{array}{l}\text { Koefisien } \\
\text { korelasi }\end{array}$ & 0,122 \\
\hline & & Sig. (2-tailed) & 0,190 \\
\hline & \multirow{2}{*}{$\begin{array}{l}\text { Mempengaruhi } \\
\text { melakukan } \\
\text { pranikah }\end{array}$} & $\begin{array}{l}\text { Koefisien } \\
\text { korelasi }\end{array}$ & 0,119 \\
\hline & & Sig. (2-tailed) & 0,202 \\
\hline & \multirow{2}{*}{$\begin{array}{l}\text { Menganggap } \\
\text { keperawanan penting }\end{array}$} & $\begin{array}{l}\text { Koefisien } \\
\text { korelasi }\end{array}$ & . \\
\hline & & Sig. (2-tailed) & . \\
\hline
\end{tabular}

\section{c. Analisa Multivariat}

Besarnya pengaruh pada Tabel 5 ditunjukkan dengan nilai $\operatorname{Exp}(B)$ atau disebut juga Odds Ratio (OR). Variabel Tingkat Pendidikan dengan nilai OR 2,710 maka responden yang jenjang pendidikannya SLTA keatas (kode I variabel independen), lebih beresiko melakukan perilaku seksual pranikah (kode I variabel dependen) sebanyak 2,710 kali lipat di bandingkan responden yang jenjang pendidikan SLTP kebawah (kode 0 variabel independen). Nilai $B=$ Logaritma Natural dari 2,710 $=0,997$. Variabel Daerah Tempat tinggal dengan nilai OR 3,477 maka responden yang tinggal di daerah perkotaan (kode I variabel independen), lebih beresiko melakukan perilaku seksual pranikah (kode I variabel dependen) sebanyak 3,477 kali lipat di bandingkan responden yang tinggal di pedesaan (kode 0 variabel independen). Nilai $B=$ Logaritma Natural dari $3,477=$ I,246. Variabel memiliki dorongan karena teman dengan OR 3,942 maka responden yang pernah mendapatkan dorongan karena teman (kode I variabel independen), lebih beresiko melakukan perilaku seksual pranikah (kode I variabel dependen) sebanyak 3,942 kali lipat di bandingkan responden yang tidak pernah mendapatkan dorongan karena teman (kode 0 variabel independen). Nilai B = Logaritma Natural dari 3,942 = I,372.

Tabel 5. Nilai Odd Rasio (OR) variabel independen terhadap perilaku seksual pranikah responden di Kalimantan Tengah

\begin{tabular}{lll}
\hline No. & Variabel independent & Nilai OR \\
\hline I & Tingkat Pendidikan & 2,710 \\
2 & Daerah Tempat Tinggal & 3,477 \\
3 & Umur pertamakali berpacaran & 0,947 \\
4 & Memiliki dorongan karena teman & 3,942 \\
& & \\
& & Nilai konstan
\end{tabular}

Berdasarkan nilai-nilai B pada perhitungan di atas, maka model persamaan yang dibentuk dari variabel yang memiliki pengaruh signifikan adalah sebagai berikut:

Logit $(\mathrm{Y})=\ln$ ro $\mathrm{P} /(\mathrm{I}-\mathrm{P})=$ nilai konstan tabel + nilai $\mathrm{B}$ variabel I + nilai $B$ variabel 2

Logit $(\mathrm{Y})=\ln \mathrm{I} P /(\mathrm{I}-\mathrm{P})=0,615+0,997$ tingkat pendidikan + I,246 daerah tempat tinggal

Aktivitas pacaran remaja yang mengarah pada perilaku seksual juga dipengaruhi oleh tingkat pendidikan. Hasil penelitian memperlihatkan remaja yang pernah melakukan perilaku seksual lebih banyak memiliki tingkat pendidikan SLTA keatas. Hal tersebut memperlihatkan bahwa remaja yang bersekolah dengan periode lebih lama dan jenjang yang lebih tinggi akan cenderung melakukan aktivitas pacaran dalam jangka waktu yang lama dibanding mereka yang putus sekolah. Karena remaja yang putus sekolah cenderung akan menikah pada usia muda. Namun, hal ini juga menunjukan bahwa pendidikan yang tinggi tidak dapat mencegah seorang remaja untuk tidak melakukan perilaku seksual dalam aktivitas pacarannya. Pengetahuan dari hasil pendidikan akan muncul dan diterapkan ketika akal budi digunakan untuk mengenali kesalahan dalam perilaku. Adanya pengaruh yang kuat dari variabel lain seperti lingkungan dan keterpaparan media dapat menjadi pengaruh kuat ajakan teman 
kencan untuk melakukan perilaku seksual. Hal ini memperlihatkan bahwa pendidikan tinggi tidak menjamin terhindar dari perilaku seksual, justru pendidikan yang tinggi membuat seseorang memiliki pengetahuan yang baik tentang perilaku seksual dan membuat remaja ingin tahu sehingga melampiaskan rasa penasarannya dengan mencoba melakukan hal yang belum pernah dilakukan yang pada akhirnya tetap melakukan perilaku seksual dari ringan hingga berat (Suidhan et al., 20l4).

Daerah tempat tinggal, perkotaan dan pedesaan juga menjadi pengaruh pergaulan remaja dalam aktivitas pacaran yang mengarah kepada perilaku seksual. Remaja yang tinggal diperkotaan akan lebih mudah mendapatkan arus informasi dan lebih lumrah dengan aktivitas pergaulan yang bebas (Purwatiningsih, 2019). Selain itu, wilayah perkotaan memiliki kompleksitas masalah sosial yang lebih tinggi sehingga remaja yang berada di perkotaan cenderung rentan mengalami gangguan psikologis karena tekanan hidup yang tinggi di tengah kepadatan penduduk. Selain, itu kawasan perkotaan lebih identik dengan keadaan masyarakat yang individualis sehingga remaja lebih mudah untuk melakukan perilaku menyimpang, salah satunya adalah perilaku seksual pranikah (Farida, 2009).

Perilaku remaja dalam aktivitas pacaran dapat dipengaruhi oleh pola pergaulan yang berkaitan erat dengan siapa saja remaja tersebut berteman. Hasil penelitian ini menunjukan bahwa ada sebagian remaja yang melakukan perilaku seksual disebabkan oleh adanya dorongan dari teman dan sebagian juga mempengaruhi teman untuk melakukan perilaku seksual, meskipun lebih banyak remaja yang melakukan perilaku seksual tanpa terpengaruh oleh teman dalam pergaulannya sehari-hari. Faktor-faktor yang mempengaruhi remaja dalam berperilaku memang sangat banyak diantaranya (Farida, 2009):

a) Faktor pemahaman terhadap agama dan iman yang kurang; b) Faktor lingkungan, seperti: orang tua (keluarga yang tidak harmonis), teman (peer group yang memberi pengaruh negatif)), masyarakat (kurang adanya kontrol akibat dari individualisme) dan media (pornografi di media cetak, pornoaksi di tempat-tempat umum atau di media TV dan internet);

c) Faktor pengetahuan dan pengalaman yang minim dan ditambah rasa ingin tahu yang berlebihan; dan

d) Faktor perubahan zaman.

Remaja yang melakukan perilaku seksual akan berakibat pada kejadian Married By Accident (MBA) dan membawa dampat buruk bagi keberlangsungan pendidikan, kesehatan mental dan reproduksi, hingga dapat berpengaruh pada keadaan ekonomi rumah tangga terlebih dibangunnya suatu keluarga tanpa kesiapan yang matang (Farida, 2009). Perilaku seksual remaja merupakan masalah bersama bagi seluruh elemen masyarakat pada suatu negara.

Kegiatan preventif untuk mencegah perilaku seksual remaja dapat dikembangkan melalui pendidikan karakter yang ditanamkan pada remaja baik dalam pendidikan formal maupun keluarga. Pengembangan pendidikan karakter juga dilakukan dalam komunitas pada skala besar, upaya-upaya yang telah dilakukan pemerintah melalui $\mathrm{BKKBN}$ dan masyarakat yang ditunjukan oleh kegiatan keagamaan. Namun tidak semua remaja menghadiri atau menerima informasi secara efektif. Jika pendidikan kesehatan remaja dapat dilakukan dengan tepat, oleh orang yang tepat, dan sesuai dengan target untuk dijangkau, ini akan berpotensi memberikan pengetahuan dan sikap positif terhadap sikap moral dan kesadaran dalam kesehatan reproduksi remaja (Ivantarina \& Ratnawati, 2020)

\section{KESIMPULAN}

Perilaku seksual pada aktivitas pacaran remaja di Kalimantan Tengah dipengaruhi oleh karakteristik latar belakang, remaja yang bertempat tinggal di perkotaan lebih rentan dan beresiko 3,477 untuk melakukan 
perilaku seksual seperti pelukan dan pegangan tangan, berciuman, meraba payudara, meraba alat kelamin dan melakukan hubungan seksual.

\section{UCAPAN TERIMA KASIH}

Terimakasih peneliti ucapkan kepada Badan Kependudukan dan Keluarga Berencana Nasional (BKKBN) yang telah mengarahkan dan mendanai hingga terwujudnya penelitian ini.

\section{REFERENSI}

I. Center for Disease Control and Prevention. (2015). Youth Risk Behavior Surveillance-United States.

https://www.cdc.gov/mmwr/volumes/65/ss/ss6506 al.htm

2. Fhadila, K. (20I7). Menyikapi perubahan perilaku remaja, Jurnal Penelitian Guru Indonesia. Jurnal Penelitian Guru Indonesia (JPGI), 2(2), I7-23.

3. Sarwono, S. W. (20II). Psikologi Remaja. Rajawali Pers.

4. Nasir, S., Suriah, \& Evi. (20I3). Perilaku Seksual Pada Remaja Yang Berpacaran Di SMA Negeri 2 Kairatu Kabupaten Seram Bagian Barat. Media Kesehatan Masyarakat Indonesia (MKMI), 250-256. https://doi.org//0.30597/mkmi.v9i4.463

5. Pinandari, A. W., Wilopo, S. A., \& Ismail, D. (20I5). Pendidikan Kesehatan Reproduksi Formal dan Hubungan Seksual Pranikah Remaja Indonesia. National Public Health Journal, I (I), 44-50.

6. Desiningrum, \& Sari. (2017). Pengalaman Berkeluarga Pada Wanita yang Menjalani Married by Accident Studi Fenomenologis Pernikahan Karena Kehamilan Diluar Nikah di Semarang. Jurnal Empati, 6(I), 338-345.

7. BKKBN. (20I7). Survey Kesehatan Reproduksi Tentang Perilaku Remaja Berpacaran dengan Gaya Berpacaran. Puslitbang BKKBN. https://www.bkkbn.go.id/

8. Notoboro, \& Magdalena. (2016). Pengaruh Aktivitas Seksual Pranikah, Ketaatan Beragama dan Sosial Ekonomi terhadap Kehamilan Remaja di Kecamatan Saptosari Gunungkidul. Jurnal Biometrika Dan Kependudukan, 5(1), 19-26.
9. Firza, F. (20II). Hubungan Antara Pengetahuan Remaja Tentang Pendidikan Seks Dengan Perilaku Seksual Pranikah Pada Remaja [UIN Sultan Syarif Kasim]. https://core.ac.uk/download/pdf/300819672.pdf

10. Winarti, Y., \& Alamsyah, W. A. B. (2020). Hubungan Peran Orang Tua dengan Inisiasi Seks Pranikah pada Remaja di Prodi SI Farmasi Universitas Muhammadiyah Kalimantan Timur. JURNAL DUNIA KESMAS, 9(3), 355-364. https://doi.org// 0.33024/jdk.v9i3.3045

II. Swarjana, K. (20I2). Metodologi Penelitian Kesehatan. CV Andi Offset.

12. Notoatmodjo, S. (20I0). Metodologi Penelitian Kesehatan. Rineka Cipta.

13. Hosmer, D. W. (20I I). Applied Logistic Regression. John Wiley \& Sons, Inc.

14. Aisyah. (20/3). Dampak Negatif Pergaulan Bebas Terhadap Generasi Muda Menurut Tinjauan Pendidikan Islam [Fakultas Tarbiyah dan Keguruan UIN Alauddin]. http://repositori.uinalauddin.ac.id/I228/I/AISYAH.pdf

I5. Sudarsono. (199I). Kenakalan Generasi Muda. PT. Rineka Cipta.

16. Suidhan, A., Seweng, A., \& Noor, N. B. (20|4). Hubungan Pengetahuan Kesehatan Reproduksi Dengan Prilaku Seks Remaja Akhir Pada Mahasiswa Kesehatan Dan Non Kesehatan Di Kab. Mamuju Prov. Sulawesi Barat. 13.

17. Farida, F. (2009). Pergaulan Bebas dan Hamil Pranikah. Analisa, 16(I), 136. https://doi.org/10.18784/analisa.v I6il.64

18. Ivantarina, D., \& Ratnawati, L. (2020). Characteristics of Mothers Which Affect The Low Coverage of Comprehensive Postpartum Service In The Working Area of Community Health Center of Kayen Kidul in Kediri Regency From January to August 2019. Jurnal Ners Dan Kebidanan Indonesia, 7(3), 161 . https://doi.org//0.21927/jnki.2019.7(3).|61-|7| 